\title{
Antioxidant properties of wood extracts and colour stability of woods
}

\author{
Papa-Niokhor Diouf, André MERLIN, Dominique PERRIN* \\ Laboratoire d'Études et de Recherches sur le Matériau Bois (LERMaB), UMR_A INRA-UHP-ENGREF 1093, BP 239, \\ 54506 Vandoeuvre-lès-Nancy Cedex, France
}

(Received 14 February 2005; accepted le 11 January 2006)

\begin{abstract}
Industrial wood extracts were selected and other extracts were prepared in the laboratory from some chosen wood species. Antioxidant capacities of extracts were measured by three methods: the oxygen uptake method, the kinetic DPPH method, and the equilibrium DPPH method. There is a fair correlation between the three methods. Total phenol contents of the extracts and colour stability of woods were measured. For the same phenol content, extracts containing condensed tannins are more antioxidant than those containing hydrolysable tannins. Colour stability is clearly correlated neither with phenol content nor with antioxidant capacity of the extracts, but it is conferred to non durable woods if impregnated with extracts of durable species. Light aging is accompanied by consumption of the most antioxidant compounds of the extracts first.
\end{abstract}

colour / wood /extract / tannin / antioxidant / polyphenol

Résumé - Les propriétés antioxydantes d'extraits de bois et la stabilité de la couleur de ces bois. Nous avons étudié des extraits industriels de bois et préparé au laboratoire les extraits de quelques essences. Nous avons mesuré le pouvoir antioxydant des extraits par trois méthodes : la mesure de la consommation d'oxygène, et deux méthodes utilisant le DPPH, l'une cinétique et l'autre à l'équilibre. Les résultats obtenus par les trois méthodes sont raisonnablement corrélés. Nous avons mesuré le contenu phénolique total des extraits et la durabilité de la couleur des bois correspondants. Pour le même contenu phénolique, les extraits contenant des tannins condensés sont plus antioxydants que ceux contenant des tannins hydrolysables. La durabilité de la couleur n'est clairement corrélée ni avec le contenu phénolique ni avec le pouvoir antioxydant des extraits; mais des extraits d'essences durables la confèrent à des essences peu durables. L'exposition à la lumière s'accompagne d'une consommation préférentielle des composés des extraits les plus antioxydants.

couleur / bois / extrait / tanin / antioxydant / polyphénol

\section{INTRODUCTION}

A study of the photochemical behaviour of the wood of grand fir (Abies grandis), a species almost without any coloured extractive, has shown that coloured photoproducts generated by a solar-type irradiation arise from oxidation reactions via free radicals coming from lignin chromophors [7]. Monitoring surface properties of grand fir samples impregnated by oak (Quercus pedunculata) extracts evidenced grand fir wood protection by these extracts. Comparison of photodegradation of grand fir and oak woods evidenced the involvement of extractives in the degradation process $[16,17]$. An ESR study showed that these phenolic coloured compounds not only act as filters, but also play a role in the radical processes involved in the photodegradation of wood: by radical transfer reactions, they deactivate radical oxygen species carrying oxidation process by producing stable phenoxyl (ФО•) free radicals [10].

Radical chemistry of plant phenolic compounds has been the subject of numerous studies in medical biology, in cosmetology, and in food research. Antioxidant capacity is measured by a number of biochemical or chemical methods. Usually these methods refer to oxidation of a more

\footnotetext{
* Corresponding author: dperrin@lermab.uhp-nancy.fr
}

or less complex substrate or to reactivity towards reference free radicals. One class of methods is based upon inhibition of oxidation of organic substrates: styrene [4], methyl or ethyl linoleate [9,28], linoleic acid [35], canola oil [33], blood plasma [36], low density lipoproteins [1], microsoms $[13,15] \ldots$ In these methods, reaction extent is measured by various means; the most direct, when available, is oxygen uptake measurement. Another group of methods include direct reaction with a free radical; the free radical scavenging capacity of compounds is measured. Enzymatic [22] or chemical [15] methods are used to prepare superoxide anion. Chemical methods are used to prepare 2,6-di-tert-butyl-4-(4'-methoxyphenyl)phenoxyl radical [19], several peroxyl radicals [20], hydroxyl radical [29], 2,2'azinobis-(3-ethylbenzothiazoline-6-sulfonic acid) $\left(\mathrm{ABTS}^{+} \cdot\right.$ ) cation radical [25]. Radiolysis is used to generate hydroxyl free radical [30] and various free radicals [2]. 2,2-diphenyl-1picrylhydrazyl free radical (DPPH) is widely used because it is a stable free radical, easy to manipulate. Generally, authors determine the quantity of scavenger necessary to obtain reaction of a certain quantity (usually $50 \%$ of the initial concentration) of DPPH after a given time (see e.g. [5, 11,34]). Other authors measure the rate constant of the bimolecular reaction of DPPH with the antioxidant $[21,26]$. Some authors use both 
methods [3,6], but links between the two methods are not clear at the present time.

The aim of this work is first to compare three different methods of measuring antioxidant capacity: inhibition of methyl linoleate autoxidation, rate constant of reaction of DPPH with wood extracts, and extent of reaction of DPPH with extracts. We also want to lighten the role of extractives in reactions spoiling colour of wood submitted to solar-type irradiation, and examine links between colour stability of a wood and antioxidant capacity of its extracts.

\section{MATERIALS AND METHODS}

\subsection{Chemicals, industrial extracts, and wood samples} labo.

Reagents were the purest grade of Fluka, Merck, Sigma or Pro-

Gall nut, sumac, and tara extracts were obtained from Silva s.r.l. (Italy), quebracho extract was obtained from Inounor (Argentina), pine bark extract from Diteco S.A. (Chile). Mimosa tannin (Tanac, Brasil) was obtained from wood and bark by counter-current extraction by water at $95{ }^{\circ} \mathrm{C}$, pecan tannin (bark and nut shells) by counter-current extraction by water with $2 \% \mathrm{~m} / \mathrm{v}$ sodium sulphite and $0.4 \% \mathrm{~m} / \mathrm{v}$ sodium carbonate, pine bark and quebracho heartwood by counter-current extraction by water and $2 \% \mathrm{~m} / \mathrm{v}$ sodium sulphite at $70{ }^{\circ} \mathrm{C}$.

Solid wood samples $(13 \times 1 \times 6 \mathrm{~cm}$ : Long. $\times$ Rad. $\times$ Tang. $)$ were obtained from Atout Bois Echantillons (Z.A. de Port Neuf, 33360 Camblanes, France).

\subsection{Extractions}

Wood chips were obtained from wood samples with a natural moisture of $8-11 \%$ (moisture was measured on separate samples), milled in a vibratory disc mill T 100 (Aurec S.A.). Meals were extracted in the "Accelerated Solvent Extraction" system ASE 200 (Dionex), a system which allows using high pressure and extraction temperature above the boiling point of solvent. Extractions were performed at $100{ }^{\circ} \mathrm{C}$ with a 100 bar pressure by a methanol/water 70:30 (v/v) mixture as the solvent. The cell volume was $22 \mathrm{~cm}^{3}$. The mass of wood meal was 8 to $10 \mathrm{~g}$, the volume of solvent was 11 to $13 \mathrm{~cm}^{3}$, both depending on the meal density. All woods except oak were extracted by the ASE 200 apparatus. Oak sawdust was washed by petroleum ether ( $1 \mathrm{~g}$ of wood for $4 \mathrm{~cm}^{3}$ of ether) then extracted at room temperature by an acetone/water mixture $(70: 30, v / v)$ for $24 \mathrm{~h}$ [16]. Extraction yields were calculated with dry wood as reference.

\subsection{Total phenol quantitation}

Two methods were used. The first one simply consists in measuring absorbance of a methanolic solution of the extract; this method is usually referred to as the " $\mathrm{OD}_{280}$ " method, and is widely used in oenology (see e.g. [32]). Practically, the extinction coefficient $\varepsilon_{280}$ was measured.

The Folin-Ciocalteu method [31] determines total phenols by producing a blue colour from reducing yellow heteropolyphosphomolybdate-tungstate anions. We used the experimental conditions of Klumpers [14]. Results are obtained in gallic acid equivalent, in $\mathrm{mg}$ gallic acid per $\mathrm{g}$ of wood. Calibration was performed with gallic acid solutions $\left(2-40 \mathrm{mg} \mathrm{L}^{-1}\right)$ in water.

\subsection{Measurement of antioxidative activity}

\subsubsection{Oxygen uptake method}

The induced oxidation of methyl linoleate by dioxygen was performed in a gas-tight borosilicate glass apparatus [8]. The solvent was butan-1-ol. Reaction temperature was $60{ }^{\circ} \mathrm{C}$ and initial conditions were as follows; linoleate concentration: $0.4 \mathrm{M}$; AIBN concentration: $910^{-3} \mathrm{M}$; extract concentration: $0.1 \mathrm{~g} / \mathrm{L}$; oxygen pressure: 150 Torr. Oxygen uptake was monitored continuously by a pressure transducer. Without any additive, oxygen uptake is roughly linear (see e.g. Fig. 5). In the presence of an antioxidant extract, oxygen consumption is slower, and we measured the antioxidant capacity of the extract by the ratio of oxygen uptake at a chosen time in the presence and in the absence of the extract. We call this antioxidant capacity index OUI, for "Oxygen Uptake Inhibition"; it should spread from 0 to $100 \%$, for poor and strong antioxidants, respectively, and would be negative for prooxidants.

\subsubsection{Kinetic DPPH method}

In this method, one considers that measuring rate constant of the reaction of 2,2-diphenyl-1-picrylhydrazyl with a hydrogen donating compound:

$$
\mathrm{DPPH}+\mathrm{RH} \rightarrow \mathrm{DPPH}-\mathrm{H}+\mathrm{R} \cdot
$$

is equivalent to estimate the mobility of this hydrogen atom and then the antioxidant capacity of RH [26]. With an excess of RH, it is easy to measure the pseudo-first order rate constant of the reaction [21]. We used a stopped-flow apparatus, the "Rapid Kinetic Accessory" SFA-11 (HI-TECH Scientific). Kinetics of reaction of extracts with DPPH was studied as follows. Methanol solutions of $210^{-4} \mathrm{M} \mathrm{DPPH}$ and of $2 \mathrm{~g} / \mathrm{L}$ extract were mixed in the stopped-flow apparatus (final concentrations $110^{-4} \mathrm{M}$ and $1 \mathrm{~g} \mathrm{~L}^{-1}$ resp.) and absorbance of DPPH at $520 \mathrm{~nm}$ was monitored; as exemplified on Figure 1, extracts usually absorb $520 \mathrm{~nm}$ light, but $1 \mathrm{~g} \mathrm{~L}^{-1}$ extract is equivalent to $610^{-3} \mathrm{M}$ gallic acid, or $310^{-3} \mathrm{M}$ ellagic acid, or $310^{-3} \mathrm{M}$ catechin, so that one can admit that extracts, which essentially contain hydrolysable or/and condensed tannins, are in large excess over DPPH. Consequently absorbance of extracts is quasi-constant during reaction and absorbance of DPPH is obtained by substracting extract absorbance from experimental absorbance, as shown in Figure 2. We quantified the reaction kinetics by measuring the half-life $t_{1 / 2}$ of DPPH in the presence of the extract. It is equivalent to measure the rate constant of the pseudo first order hydrogen transfer reaction as, in first order conditions, $t_{1 / 2}$ is simply related to the rate constant $k$ :

$$
k=\ln 2 / t_{1 / 2} \text {. }
$$

In fact, extracts are complex mixtures so that rate constant is not unique for an extract, the reason why we preferred to measure $t_{1 / 2}$. The smaller $t_{1 / 2}$, the more efficient the antioxidant. 


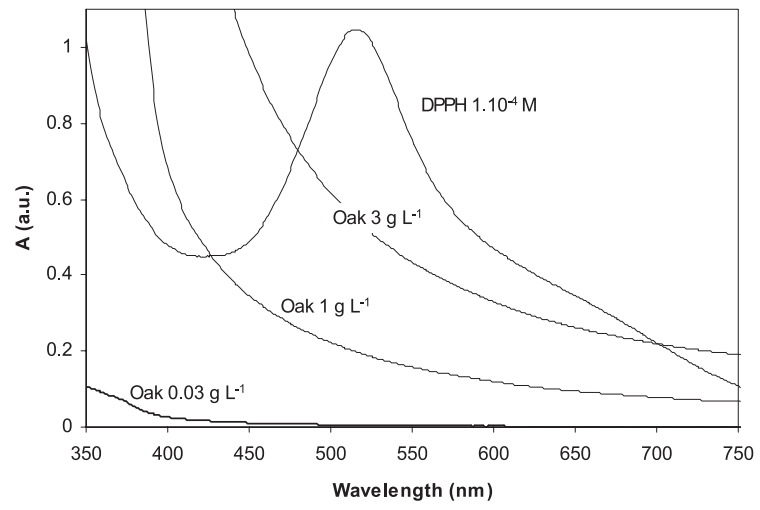

Figure 1. Absorption spectra of methanol solutions of $1.010^{-4} \mathrm{M}$ DPPH and of oak extract at $0.3,1.0$, and $3.0 \mathrm{~g} \mathrm{~L}^{-1}$.

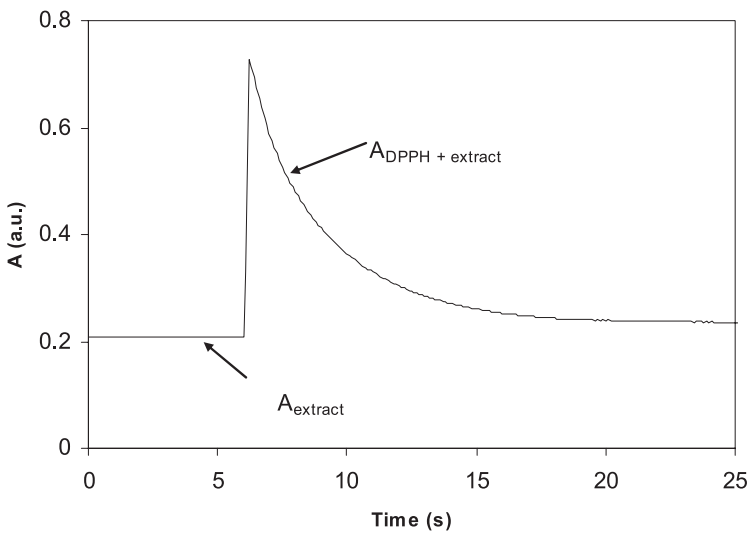

Figure 2. Absorbance at $520 \mathrm{~nm}$ during reaction of $1.010^{-4} \mathrm{M} \mathrm{DPPH}$ and $1.0 \mathrm{~g} \mathrm{~L}^{-1}$ oak extract in methanol at $30^{\circ} \mathrm{C}$.

\subsubsection{Equilibrium DPPH method}

Generally, if the extract is not in large excess over DPPH, the reaction attains an equilibrium. A very widely used method consists in measuring the concentration $\mathrm{C}_{50}$ of a compound necessary to reduce by $50 \%$ the initial quantity of DPPH $[5,11,34,37]$. Analyses are supposed to be done at equilibrium; in fact, the equilibrium times are very different depending on the extracts. In order to approach equilibrium, we measured $\mathrm{C}_{50}$ at $24 \mathrm{~h}$ when studying industrial extracts, even though at this time, equilibrium was not always reached; longer times are not convenient as DPPH slowly reacts with methanol. Later, for laboratory extracts, we measured $\mathrm{C}_{50}$ at $30 \mathrm{~min}$, as done by most authors (e.g. [3]). In all cases, solvent was methanol, DPPH concentration was $1.010^{-4} \mathrm{M}$ and temperature was $30^{\circ} \mathrm{C}$. In this test, extract is generally not in high excess on DPPH and we have checked that the extract absorbance at $520 \mathrm{~nm}$ is negligible compared to DPPH absorbance, as it may be seen on Figure 1 for oak extract at a concentration of $30 \mathrm{mg} \mathrm{L}^{-1}$.

\subsection{Colour measurements and wood aging}

Accelerated photo-aging of solid wood samples was obtained in a SEPAP chamber (MPC, France) equipped with mercury vapour lamps with a light flow of $5 \mathrm{~mW} \mathrm{~cm} \mathrm{~cm}^{-2}$ at $360 \mathrm{~nm}$, about 50 times

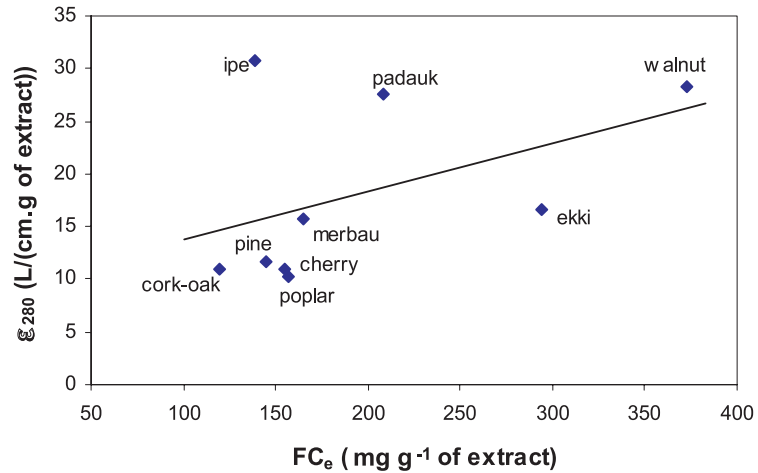

Figure 3. Correlation between $\varepsilon_{280}$ and total phenol content by the Folin method.

as much as the solar irradiation at noon (sea level, $45^{\circ}$ north latitude). Samples, rotating at constant speed and distance from the sources, were exposed during $500 \mathrm{~h}$ at $55{ }^{\circ} \mathrm{C}$. Colour was measured in the CIE-L*a*b* system [12] with a colorimeter (Spectro-color, Dr Lange Gmbh). The maximum for $\mathrm{L}^{*}$ is 100 (perfect reflecting diffuser) and the minimum is 0 (black). Positive $a^{*}$ is red, negative $a^{*}$ is green. Positive $b^{*}$ is yellow, negative $b^{*}$ is blue. There is a delta value associated with each chromatic coordinate; these values may be used to compare a sample and a standard, or, as here, to measure evolution of a sample. The total colour variation (or difference) $\Delta \mathrm{E}^{*}$ is defined as:

$$
\Delta \mathrm{E} *=\left(\Delta \mathrm{L} *^{2}+\Delta \mathrm{a} *^{2}+\Delta \mathrm{b} *^{2}\right)^{1 / 2}
$$

Colour variations due to photo-aging were measured after $500 \mathrm{~h}$ of aging with the initial colour (before irradiation) as a reference.

\section{RESULTS}

For extracts prepared in the laboratory, extraction yields are reported in Table I: lowest yields are obtained for poplar wood and pine bark. The total phenolic contents obtained by the Folin-Ciocalteu method are given here by reference to dry wood $\left(\mathrm{FC}_{\mathrm{w}}\right)$ and by reference to dry extract $\left(\mathrm{FC}_{\mathrm{e}}\right)$. The total phenolic contents measured by extinction coefficients at $280 \mathrm{~nm}$ are also reported in this table. Even though phenol titration by measuring $\varepsilon_{280}$ is considered to be a very approximate method, correlation between the two methods is fair (coefficient of determination $r^{2}=0.21$ ), as can be seen on Figure 3. On Figure 4, we have reported the total (Folin) phenol content versus the extraction yield; correlation is rather good $\left(r^{2}=0.56\right)$, indicating that extracts essentially contain phenolics, or, at least, that they all contain approximately the same ratio of phenolics.

For the sake of clarity, inhibition of the autoxidation of methyl linoleate is illustrated on two figures: Figure 5 gives the results obtained with industrial extracts and Figure 6 with laboratory extracts. Both figures show that most of our extracts inhibit the AIBN initiated oxidation of methyl linoleate. Of the industrial extracts, pine, walnut-tree and pecan extracts are the less efficient while quebracho, mimosa and gall nut are the most antioxidant. Among laboratory extracts, pine, cork-oak and poplar are the less antioxidant while oak is very efficient. 
Table I. Extraction yields and phenolic contents of extracts prepared in the laboratory using the ASE ${ }^{\circledR} 200$ system (methanol/water 70:30 v/v) except for european oak (cold maceration in acetone/water 70:30 v/v).

\begin{tabular}{lcccc}
\hline Species & Extraction yield (\%) & $\begin{array}{c}\mathrm{FC}_{\mathrm{e}} \\
\mathrm{mg} \mathrm{g}^{-1} \text { of extract }\end{array}$ & $\begin{array}{c}\mathrm{FC}_{\mathrm{w}} \\
\mathrm{mg} \mathrm{g}^{-1} \text { of wood }\end{array}$ & $\begin{array}{c}\varepsilon_{280} \\
\mathrm{~L} /(\mathrm{cm} . \mathrm{g} \mathrm{of} \mathrm{extract)}\end{array}$ \\
\hline Ekki & 3.4 & 294 & 10.0 & 16.7 \\
European oak & 8.3 & - & - & - \\
Cork oak & 5.7 & 120 & 6.9 & 10.9 \\
Ipe & 14.7 & 139 & 20.4 & 30.7 \\
Merbau & 4.0 & 165 & 6.6 & 15.7 \\
European cherry & 8.2 & 157 & 12.9 & 10.2 \\
European walnut & 8.4 & 373 & 31.3 & 28.2 \\
Padauk & 11.0 & 208 & 22.9 & 27.6 \\
Poplar & 2.9 & 155 & 4.5 & 10.9 \\
Pine & 2.0 & 145 & 2.9 & 11.7 \\
\hline
\end{tabular}

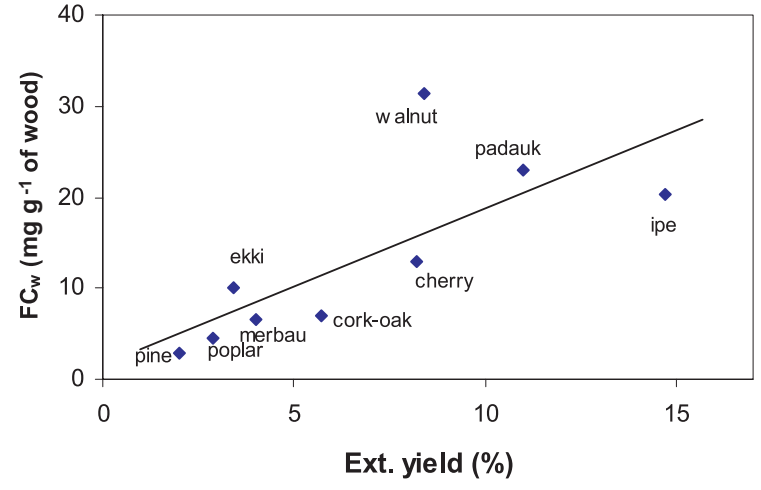

Figure 4. Link between total phenol content and extraction yield.

Antioxidative capacities [OUI (\%)] defined as the ratio of oxygen uptake at $3.5 \mathrm{~h}$ in the presence and in the absence of an extract, are reported in Table II for extracts and for two compounds: catechin, a model for condensed tannins, and gallic acid, which may be considered to be a model for hydrolysable tannins. OUI vary from $0 \%$ for industrial pine bark extract to $79 \%$ for quebracho extract, which is even more efficient than catechin; quebracho is known to essentially contain condensed (i.e. catechic) tannins. Let us notice that the time when OUI is measured is arbitrary; its choice may affect the ranking of extracts: for instance, oak extract is more efficient than walnut extract before $3 \mathrm{~h}$ and less efficient after $3.5 \mathrm{~h}$.

Kinetics of reaction of extracts with DPPH was studied. Results are presented in Table II. In this table, each half-life is the mean of three measures, and coefficients of variation range from 2 to $14 \%$ (mean $8.8 \%$ ). Of the industrial extracts, tara and walnut-tree extracts are the slowest while mimosa, quebracho and sumac are the most rapid. Among laboratory extracts, walnut-tree extract is by far the most efficient while reactions of poplar, cork-oak and especially pine extracts are very slow.

The same reaction - of extracts with DPPH - has been studied at $30{ }^{\circ} \mathrm{C}$ in methanol, with DPPH at the initial concentration of $1.010^{-4} \mathrm{M}$ and various concentrations of extracts. We determined the initial concentration of each extract necessary to decrease the initial DPPH concentration by $50 \%\left(\mathrm{C}_{50}\right)$ after $24 \mathrm{~h}$ for the industrial extracts and after $30 \mathrm{~min}$ for the laboratory extracts. Results are shown in Table II; coefficients of variation are about $4 \%$. Although the two groups of extracts have not been tested at the same reaction time, model compounds were tested at the two times so that different extract may be compared. Poplar and pine extracts are the less efficient of the laboratory and industrial extracts, respectively; gall nut and walnut-tree are the most efficient of the laboratory and industrial extracts, respectively.

In order to examine links between wood extracts and colour stability of wood, we have measured, for the woods the extracts of which have been studied above, colour evolution during exposure of a solid wood sample to a solar-type light. Variation of colour of these woods after a $500 \mathrm{~h}$ irradiation is reported in Table III. Let us note that, among the woods with the less stable colour, padauk lightens while pine and poplar darken. Padauk is known to contain an unstable dye which immediately bleaches under irradiation. Pine and poplar, strongly darkening woods, are also the woods which contain the smallest amount of extracts. Pieces of these woods were impregnated under vacuum with $10 \mathrm{~g} \mathrm{~L}^{-1}$ water/ethanol (70:30 v/v) solutions of extracts of the other species of Table III. After drying three days, these samples were exposed to light the same way as the untreated samples and variations of chromatic coordinates after $500 \mathrm{~h}$ are reported in Table IV for poplar and in Table $\mathrm{V}$ for pine wood.

A last experiment has been performed with an oak sawdust sample. A thin bed of a part of the sawdust was let under a mercury vapour lamp $\left(3 \mathrm{~mW} \mathrm{~cm} \mathrm{~cm}^{-2}\right.$ at $\left.360 \mathrm{~nm}\right)$ during 5 days. Irradiated and non irradiated sawdusts were extracted. Total phenol content and antioxidant capacity of both extracts were measured. After irradiation, phenol content was reduced by $12 \%$, OUI decreased by $50 \%, t_{1 / 2}$ increased by $52 \%$, and $\mathrm{C}_{50}$ increased by $88 \%$. So we observed a strong decrease of antioxidant activity, with a concomitant decrease of total phenols. Nevertheless, this last decrease is comparatively low: the most efficient phenols are destroyed preferentially by light. 


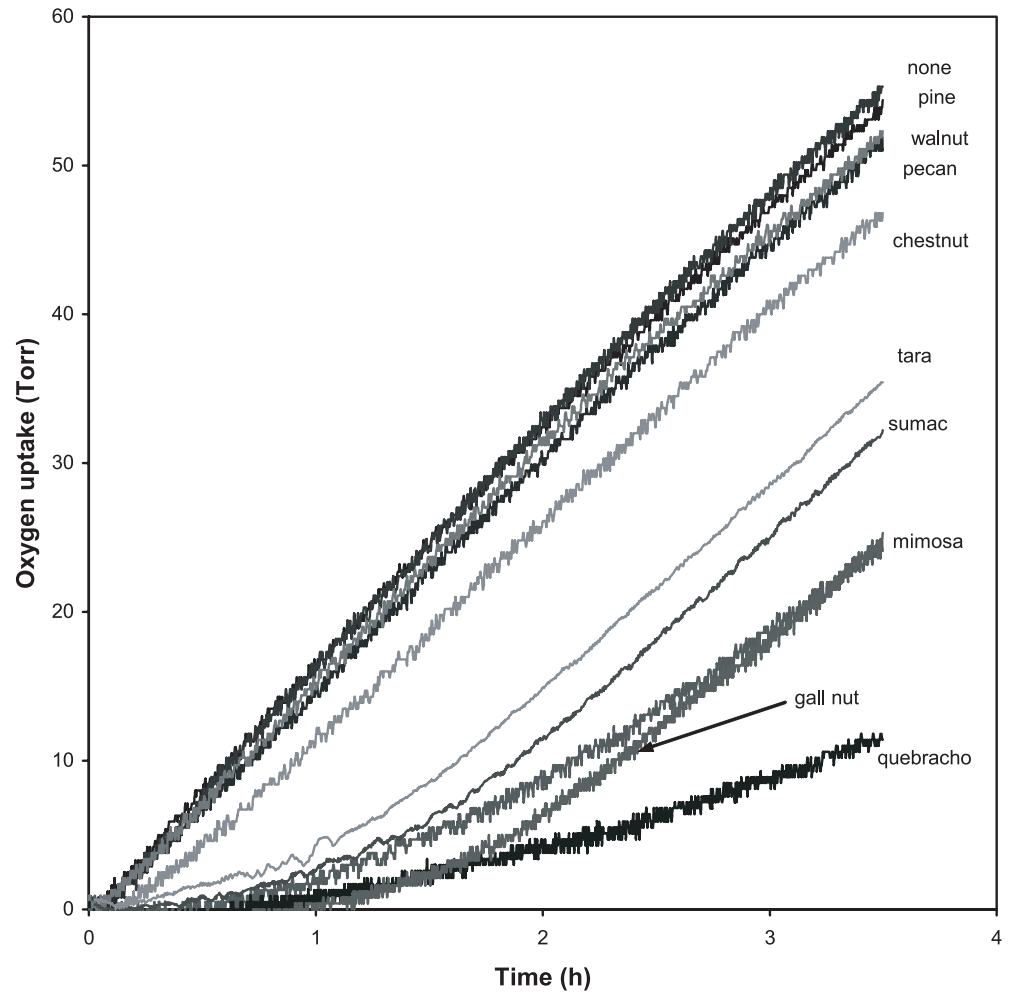

Figure 5. Influence of industrial extracts $\left(0.1 \mathrm{~g} \mathrm{~L}^{-1}\right)$ on the autoxidation of methyl linoleate $(0.4 \mathrm{M})$ induced by $\mathrm{AIBN}\left(9.10^{-3} \mathrm{M}\right)$ at $60{ }^{\circ} \mathrm{C}$ in butan-1-ol. $\mathrm{P}\left(\mathrm{O}_{2}\right)=150$ Torr.

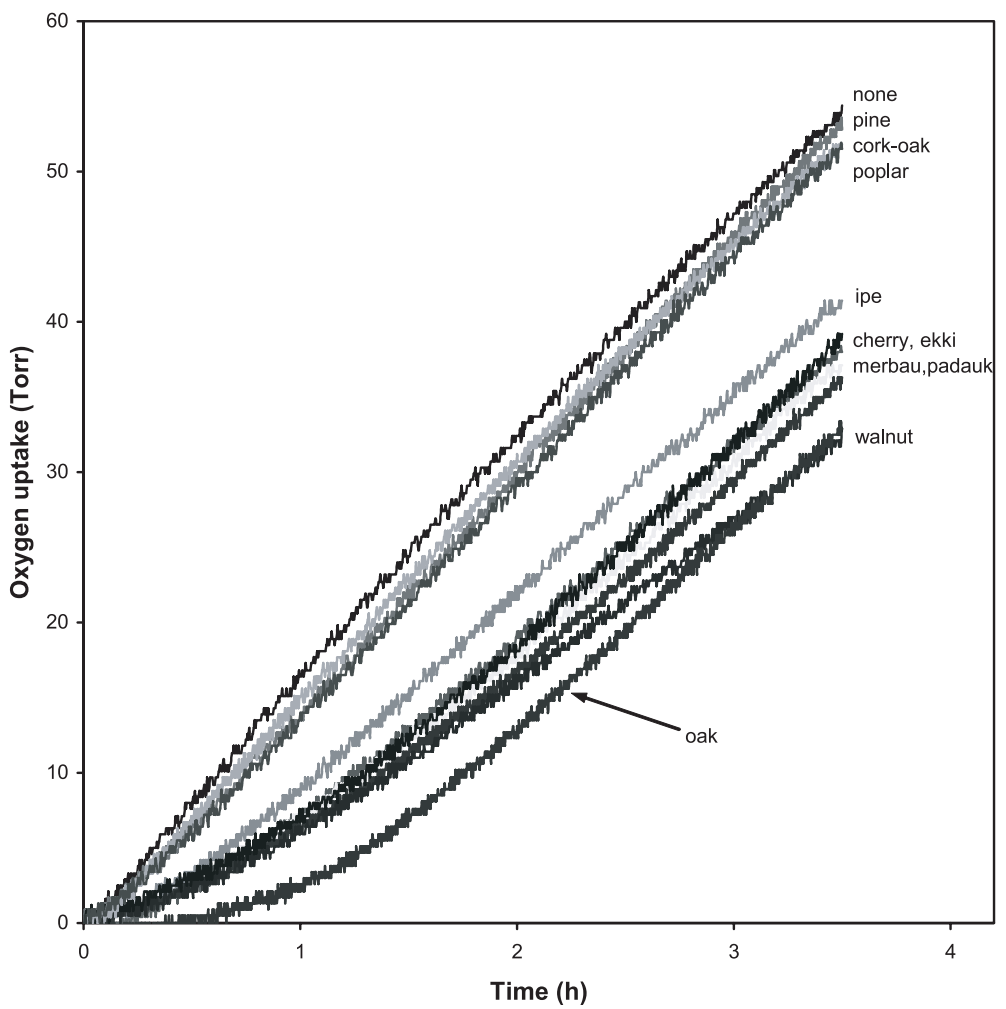

Figure 6. Influence of laboratory extracts $\left(0.1 \mathrm{~g} \mathrm{~L}^{-1}\right)$ on the autoxidation of methyl linoleate $(0.4 \mathrm{M})$ induced by $\mathrm{AIBN}\left(9.10^{-3} \mathrm{M}\right)$ at $60{ }^{\circ} \mathrm{C}$ in butan-1-ol. $\mathrm{P}\left(\mathrm{O}_{2}\right)=150$ Torr. 
Table II. Antioxidant and radical scavenging properties of extracts and model compounds.

\begin{tabular}{|c|c|c|c|c|}
\hline Extract & $\begin{array}{l}\text { OUI } \\
(\%)\end{array}$ & $\begin{array}{r}t_{1 / 2} \\
(\mathrm{~s})\end{array}$ & $\begin{array}{l}\mathrm{C}_{50} 24 \mathrm{~h} \\
\left(\mathrm{mg} \mathrm{L}^{-1}\right)\end{array}$ & $\begin{array}{r}\mathrm{C}_{50} 30 \mathrm{~min} \\
\quad\left(\mathrm{mg} \mathrm{L}^{-1}\right)\end{array}$ \\
\hline \multicolumn{5}{|l|}{ Industrial extracts } \\
\hline Chestnut & 14.0 & 1.13 & 2.09 & \\
\hline Gall nut & 53.5 & 1.17 & 0.41 & \\
\hline Mimosa & 55.7 & 0.43 & 2.24 & \\
\hline Walnut & 3.9 & 2.73 & 2.31 & \\
\hline Hickory & 6.3 & 0.73 & 2.13 & \\
\hline Pine & 0.0 & 1.93 & 2.64 & \\
\hline Quebracho & 79.0 & 0.67 & 1.67 & \\
\hline Sumac & 38.1 & 0.70 & 0.75 & \\
\hline Tara & 36.4 & 6.57 & 0.72 & \\
\hline \multicolumn{5}{|c|}{ Laboratory extracts } \\
\hline Ekki & 30.1 & 4.00 & & 12.1 \\
\hline European oak & 39.5 & 2.20 & & 6.1 \\
\hline Cork oak & 5.0 & 5.55 & & 48.2 \\
\hline Ipe & 23.9 & 2.03 & & 30.9 \\
\hline Merbau & 31.8 & 2.30 & & 11.3 \\
\hline European cherry & 27.9 & 2.87 & & 10.1 \\
\hline European walnut & 39.5 & 0.43 & & 4.8 \\
\hline Padauk & 33.3 & 1.53 & & 14.5 \\
\hline Poplar & 5.0 & 4.80 & & 160 \\
\hline Pine & 2.9 & 11.10 & & 96.1 \\
\hline \multicolumn{5}{|l|}{ Model compounds } \\
\hline Gallic acid & 71.3 & 0.40 & 0.16 & 1.0 \\
\hline Catechin & 75.2 & 0.22 & 0.40 & 12.1 \\
\hline
\end{tabular}

Table III. Variation of chromatic coordinates of woods at the end of the exposition to a solar-type light.

\begin{tabular}{lllll}
\hline Wood species & $\Delta \mathrm{L}^{*}$ & $\Delta \mathrm{a}^{*}$ & $\Delta \mathrm{b}^{*}$ & $\Delta \mathrm{E}^{*}$ \\
\hline Padauk & 12.4 & -20.1 & -1.1 & 23.6 \\
Cork oak & 9.6 & -1.7 & 2.4 & 10.0 \\
Ipe & 6.3 & -0.6 & 4.4 & 7.7 \\
Merbau & 1.1 & -4.6 & -2.7 & 5.4 \\
Ekki & -0.2 & -3.8 & -0.3 & 3.8 \\
European walnut & -0.8 & 2.1 & 8.0 & 8.3 \\
European cherry & -3.9 & -1.8 & -3.5 & 5.5 \\
European oak & -4.7 & 2.4 & 2.7 & 5.9 \\
Poplar & -12.5 & 8.2 & 14.0 & 20.4 \\
Pine & -15.2 & 6.4 & 11.1 & 19.9 \\
\hline
\end{tabular}


Table IV. Variation of chromatic coordinates of poplar wood impregnated by extracts of different species at the end of the exposition to a solar-type light.

\begin{tabular}{lrrrr}
\hline Impregnating extract & $\Delta \mathrm{L}^{*}$ & $\Delta \mathrm{a}^{*}$ & $\Delta \mathrm{b}^{*}$ & \multicolumn{1}{c}{$\Delta \mathrm{E}^{*}$} \\
\hline Padauk & 2.6 & -17.9 & -1.3 & 18.1 \\
Ipe & -2.5 & 3.3 & 3.0 & 5.1 \\
Merbau & -3.4 & -2.3 & 0.8 & 4.2 \\
European walnut & -4.4 & 3.1 & 7.9 & 9.5 \\
Cork oak & -6.5 & 4.8 & 5.3 & 9.7 \\
Ekki & -6.9 & 2.1 & 8.6 & 11.2 \\
European cherry & -9.8 & 5.3 & 8.6 & 14.1 \\
None & -12.5 & 8.2 & 14.0 & 20.4 \\
\hline
\end{tabular}

Table V. Variation of chromatic coordinates of pine wood impregnated by extracts of different species at the end of the exposition to a solar-type light.

\begin{tabular}{|c|c|c|c|c|}
\hline Impregnating extract & $\Delta \mathrm{L}^{*}$ & $\Delta \mathrm{a}^{*}$ & $\Delta \mathrm{b}^{*}$ & $\Delta \mathrm{E}^{*}$ \\
\hline Padauk & -0.8 & -18.7 & -4.2 & 19.2 \\
\hline Ipe & -7.3 & 1.6 & -0.8 & 7.5 \\
\hline Cork oak & -8.5 & 2.4 & 1.8 & 9.0 \\
\hline Ekki & -9.1 & -0.2 & 5.7 & 10.7 \\
\hline Merbau & -9.9 & -0.5 & 1.2 & 10.0 \\
\hline European walnut & -10.8 & 2.9 & 5.6 & 12.5 \\
\hline European cherry & -14.1 & 4.4 & 3.9 & 15.2 \\
\hline None & -15.2 & 6.4 & 11.1 & 19.9 \\
\hline
\end{tabular}

\section{DISCUSSION}

\subsection{Measurement of antioxidant capacity}

As we have used three methods to measure antioxidant capacity of extracts, one may want to correlate the three types of results. First, let us recall the mechanism generally invoked for induced oxidation of polyunsaturated fatty acids (see e.g. $[18,27])$ :

\begin{tabular}{|c|c|c|c|}
\hline inducer & $\rightarrow$ & $2 \mathrm{R} \cdot$ & $\left(i_{1}\right)$ \\
\hline $\mathrm{R} \cdot+\mathrm{O}_{2}$ & $\rightarrow$ & $\mathrm{RO}_{2}$. & $\left(i_{2}\right)$ \\
\hline $\mathrm{RO}_{2} \cdot+\mathrm{LH}$ & $\rightarrow$ & $\mathrm{RO}_{2} \mathrm{H}+\mathrm{L} \cdot$ & $\left(i_{3}\right)$ \\
\hline $\mathrm{L} \cdot+\mathrm{O}_{2}$ & $\leftrightarrows$ & $\mathrm{LO}_{2}$ & $(2)(-2)$ \\
\hline $\mathrm{LO}_{2} \cdot+\mathrm{LH}$ & $\rightarrow$ & $\mathrm{LO}_{2} \mathrm{H}+\mathrm{L}$ & (3) \\
\hline $\mathrm{LO}_{2} \cdot+\mathrm{LO}_{2} \cdot$ & $\rightarrow$ & & $\left(t_{1}\right)$ \\
\hline $\mathrm{LO}_{2} \cdot+\mathrm{L} \cdot$ & $\rightarrow$ & non radical products & $\left(t_{2}\right)$ \\
\hline $\mathrm{L} \cdot+\mathrm{L} \cdot$ & $\rightarrow$ & & $\left(t_{3}\right)$ \\
\hline
\end{tabular}

In the present case, the inducer is AIBN and LH stands for the substrate to be oxidized, methyl linoleate; in the simplest case - high pressure of oxygen - the termination steps reduce to $\left(t_{1}\right)$. When an antioxidant $\Phi O H$ is present, it donates its mobile $\mathrm{H}$ atom to free radicals; if the $\Phi O$. radical produced is unreactive, it stops the kinetic chain of the oxidation (and so is called a chain breaking antioxi- dant) and it reacts only (or mainly) in new termination steps:

$\begin{array}{llll}\mathrm{LO}_{2} \cdot+\Phi O H & \rightarrow & \mathrm{LO}_{2} \mathrm{H}+\Phi \mathrm{O} \cdot & (4) \\ \mathrm{L} \cdot+\Phi \mathrm{H} & \leftrightarrows & \mathrm{LH}+\Phi \mathrm{O} \cdot & (5)(-5) \\ \Phi O \cdot+\Phi \mathrm{O} \cdot & \rightarrow & & \left(t_{4}\right) \\ \mathrm{LO}_{2} \cdot+\Phi O \cdot & \rightarrow & \text { non radical products } & \left(t_{5}\right) \\ \mathrm{L} \cdot+\Phi \mathrm{O} \cdot & \rightarrow & & \left(t_{6}\right)\end{array}$

Reaction (4) is considered to be the key step for the antioxidant efficiency of $\Phi O H$; this reaction is very similar to the reaction of $\Phi \mathrm{OH}$ with DPPH:

$$
\Phi O H+\mathrm{DPPH} \rightarrow \quad \Phi \mathrm{O} \cdot+\mathrm{DPPH}-\mathrm{H}
$$

so that one is entitled to expect a correlation between OUI and $t_{1 / 2}$; this correlation should be negative as the faster reaction (4), the higher OUI, and, if kinetics of reaction (6) parallels that of reaction (4), the smaller $t_{1 / 2}$. Figure 7 shows a fair negative correlation (OUI $\left.=-16 \ln \left(t_{1 / 2}\right)+39 ; r^{2}=0.45\right)$ between OUI and $t_{1 / 2}$.

Measurement of $\mathrm{C}_{50}$ is one of the most widespread tests for antioxidant activity, and one may wonder if it is correlated with OUI measurement. As $\mathrm{C}_{50}$ has been measured in different conditions for industrial and laboratory extracts, the two series of results will be examined separately. Figure 8 shows OUI and $\mathrm{C}_{50}$ for laboratory extracts and model compounds. As expected, these two parameters are correlated, even though correlation is not linear $\left(\mathrm{C}_{50}=430 \mathrm{OUI}^{-1.06} ; r^{2}=0.83\right)$ : high OUI values correspond to low $\mathrm{C}_{50}$ values and when $\mathrm{C}_{50}$ is high, OUI is low. 


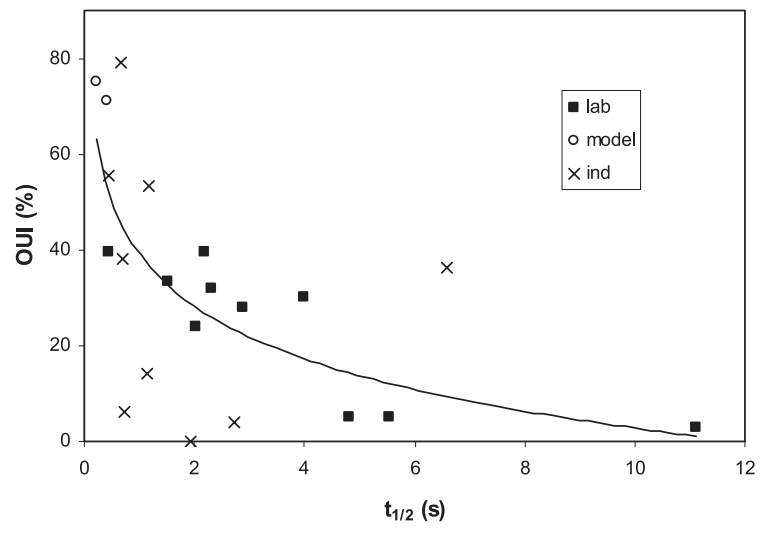

Figure 7. Correlation between antioxidant capacities measured by the oxygen uptake method (OUI) and by DPPH half-life $\left(t_{1 / 2}\right)$ for industrial (ind) extracts, laboratory (lab) extracts, and model compounds (model).

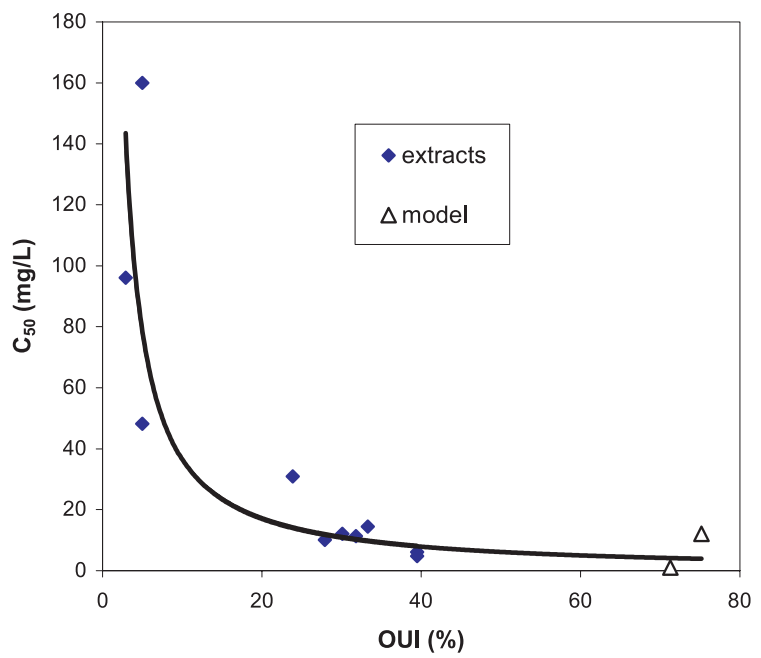

Figure 8. Correlation between antioxidant capacity measured by the oxygen uptake method (OUI) and by $\mathrm{C}_{50}$ for laboratory extracts and model compounds.

For industrial extracts the same correlation has been looked for: Figure 9 shows OUI and $\mathrm{C}_{50}$ for these extracts; on this figure, we have treated separately extracts containing essentially hydrolysable tannins (esters of an aliphatic polyol and phenolic - gallic, ellagic, or hexahydroxydiphenic acids) and those containing condensed tannins (oligomers of polyhydroxyflavan-3-ol units) $[23,24]$; we have added our model compounds, gallic acid for hydrolysable tannins and catechin for condensed tannins: correlation between OUI and $\mathrm{C}_{50}$ is fair $\left(r^{2}=0.61\right)$ for extracts containing condensed tannins; nevertheless, catechin is not in line with them. Correlation is very good $\left(r^{2}=0.95\right)$ for extracts containing hydrolysable tannins, including gallic acid.

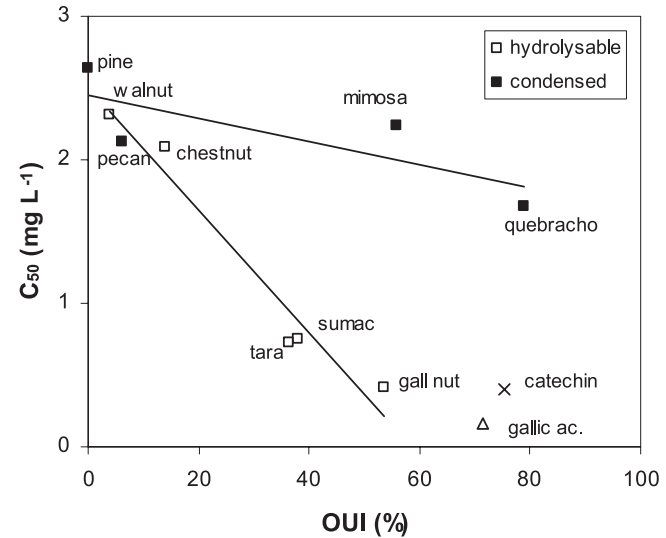

Figure 9. Correlation between antioxidant capacity measured by the oxygen uptake method (OUI) and by $\mathrm{C}_{50}$ for industrial extracts.

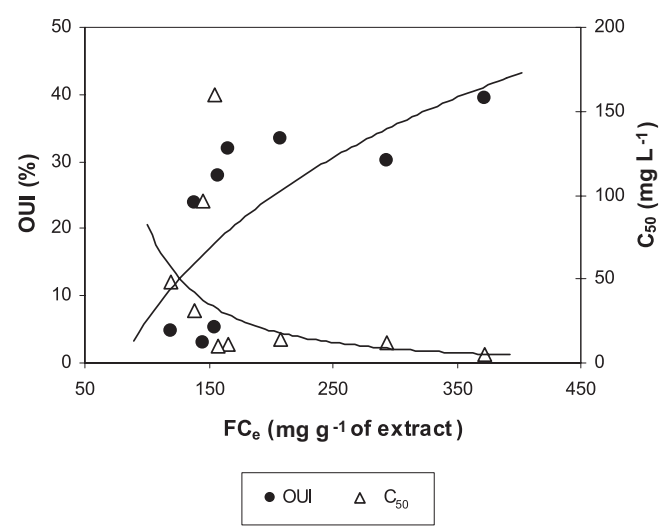

Figure 10. Correlation between phenol content of laboratory extracts and their antioxidant power as measured by OUI and $\mathrm{C}_{50}$.

\subsection{Phenol content of extracts and antioxidant capacity}

Phenols contained in laboratory extracts have been quantified by the Folin-Cioccalteu method; on Figure 10, we report antioxidant capacities OUI and $\mathrm{C}_{50}$ versus this total phenol content. It is reasonably correlated with both antioxidation parameters.

For industrial extracts, total phenol content was quantified by $\varepsilon_{280}$. Figure 11 shows the antioxidant capacity OUI as a function of this phenol content; clearly one obtains distinct correlations for the two types of extracts; antioxidant power increases with phenol content, and condensed tannins are more antioxidant than hydrolysable tannins.

\subsection{Light stability of wood colour}

Colour variation $\Delta \mathrm{E}^{*}$ of solid wood samples (Tab. III) is not clearly correlated with extraction yield (Tab. I), neither is it with total phenol content $\left(\mathrm{FC}_{\mathrm{w}}\right.$, in mg per $\mathrm{g}$ of wood, Tab. I). Nevertheless, woods containing the less extracts and with the lowest phenol content - pine and poplar - are also the less resistant to light. As we have already noticed, padauk is a special 


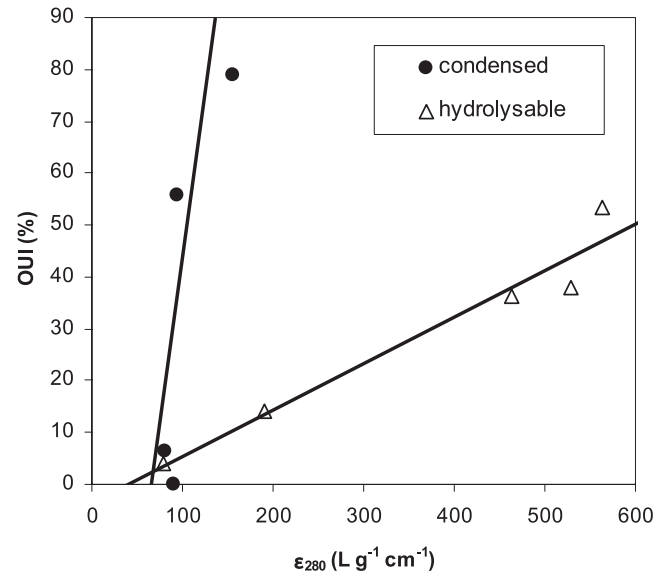

Figure 11. Correlation between phenol content of industrial extracts and their antioxidant power as measured by OUI.

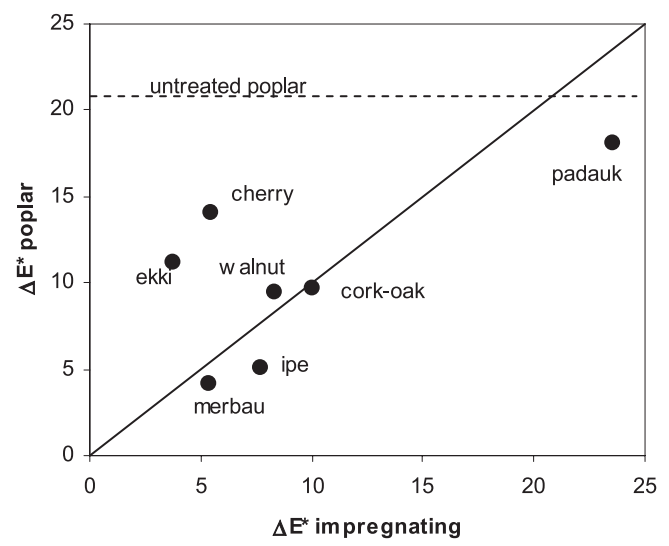

Figure 12. Correlation between $\Delta \mathrm{E}^{*}$ of wood species containing the extracts used to impregnate poplar wood and $\Delta \mathrm{E}^{*}$ of impregnated poplar.

case; it lightens while pine and poplar darken, but it is known to contain an unstable dye which immediately bleaches under irradiation.

Poplar wood was impregnated with extracts of other woods; on Figure 12, we report the colour variation of impregnated poplar wood as a function of the colour variation of woods the extracts of which were used to impregnate poplar. Let us note that impregnated poplar is always more stable than the raw wood. The diagonal points indicate the value of $\Delta \mathrm{E}^{*}$ if stabilities of stable species were totally transferred to poplar: one can see that walnut, cork-oak, ipe, and merbau efficiently transfer their stability to poplar.

Impregnation of pine produced similar results. We compared colour variations for poplar and pine woods impregnated by extracts of other species; correlation line of Figure 13 $\left(r^{2}=0.86\right)$ is not far from the diagonal line: impregnated wood species (poplar or pine) have no influence on light aging, only the impregnating extracts are important.

Another object of this study was to examine relations between colour stability of a wood species and antioxidant capacity of its extracts. One expects that wood be protected by

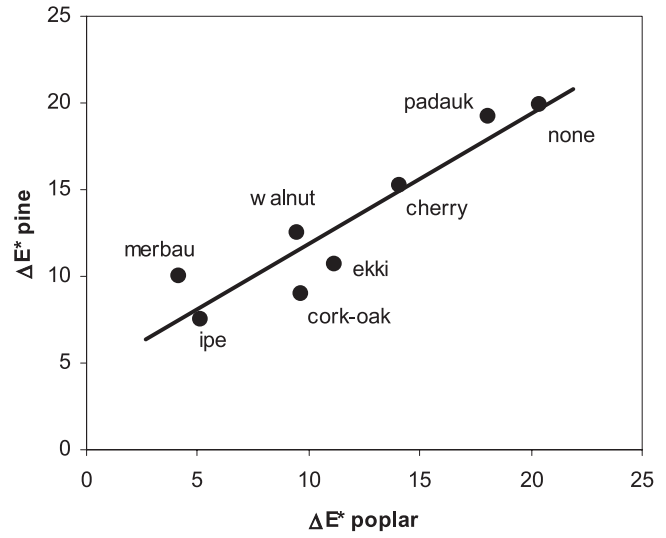

Figure 13. Correlation between $\Delta \mathrm{E}^{*}$ of impregnated pine wood and $\Delta \mathrm{E}^{*}$ of impregnated poplar wood.

its extractives not only because of their efficiency but also because of their quantity (extraction yield $\rho$ ); so we have looked for correlations between $\Delta \mathrm{E}^{*}$ and the product (extraction yield) $\mathrm{x}$ (antioxidant capacity), practically $\rho \times$ OUI, or $\rho / t_{1 / 2}$, or $\rho / C_{50}$. Though there is no clear evidence of a global correlation, species with a low antioxidant capacity, poplar and pine, happen to be the less colour durable; on the contrary, walnut, which has the highest antioxidant capacity according to the three methods (OUI, $t_{1 / 2}$, and $\mathrm{C}_{50}$ ) is light resistant. No correlation between colour variation of impregnated poplar or pine and antioxidant capacity of the impregnating extracts is obvious either.

\section{CONCLUSION}

The three methods used here to measure antioxidant capacities of wood extracts - oxygen uptake method, kinetic DPPH method, and equilibrium DPPH method - are reasonably correlated. For the same phenol content, extracts containing condensed tannins are more antioxidant than those containing hydrolysable tannins.

Stability of the natural colour of a wood exposed to a solartype irradiation is directly correlated neither with its global extract content, nor with the total phenol content of these extracts. When natural colour of a wood is unstable, impregnating this wood with extracts of a more photoresistant wood may be a novel methodology to stabilize a conferred colour. Choosing a wood species for woodworking involves a lot of parameters more important than colour stability: availability, mechanical properties, machinability, biological durability. But, for most of wood species used outdoors, colour is not stable enough and it is necessary to treat wood surface to confer it a durable colour before spraying a transparent finish. Using natural products for this treatment is a good practice in the present perspective of "green" chemistry as extraction certainly is an environmentally friendly alternative to synthesis.

Acknowledgements: We acknowledge the financial support received from ADEME (Agreement 98-01-056) and the Action intégrée franco-marocaine (MA/01/08). We are grateful to I. El Bakali who prepared most of the extracts. 


\section{REFERENCES}

[1] Aejmelaeus R., Metsa-Ketela T., Laippala P., Solakivi T., Alho H., Ubiquinol-10 and total peroxyl radical trapping capacity of LDL lipoproteins during aging: the effects of Q-10 supplementation, Molec. Aspects Med. 18 (1997) 113-120.

[2] Bors W., Heller W., Michel C., Saran M., Flavonoids as antioxidants: determination of radical-scavenging efficiencies, Meth. Enzymol. 186 (1990) 343-354.

[3] Brand-Williams W., Cuvelier M.E., Berset C., Use of a free radical method to evaluate antioxidant activity, Lebensm.-Wiss. U.Technol. 28 (1995) 25-30.

[4] Burton G.W., Doba T., Gabe E.J., Hughes L., Lee F.L., Prasad L., Ingold K.U., Autoxidation of biological molecules. 4- Maximizing the antioxidant activity of phenols, J. Am. Chem. Soc. 107 (1985) 7053-65.

[5] Chen Y., Wang M., Rosen R.T., Ho C.-T., 2,2-diphenyl1-picrylhydrazyl radical-scavenging active components from Polygonum multiflorum Thunb., J. Agric. Food Chem. 47 (1999) 2226-2228.

[6] Dangles O., Fargeix G., Dufour C., One-electron oxidation of quercetin and quercetin derivatives in protic and non protic media, J. Chem. Soc. Perkin Trans. 2 (1999) 1387-95.

[7] Dirckx O., Triboulot M.C., Merlin A., Déglise X., Modification de la couleur du bois d'Abies grandis exposé à la lumière solaire, Ann. Sci. For. 49 (1992) 425-447.

[8] El Oualja H., Perrin D., Martin R., Kinetic study of the thermal oxidation of all-trans- $\beta$-carotène and evidence of its antioxigen properties, New J. Chem. 19 (1995) 863-872.

[9] El Oualja H., Perrin D., Martin R., Influence of $\beta$-carotene on the induced oxidation of ethyl linoleate, New J. Chem. 19 (1995) 1187 1198.

[10] Godard V., Étude de la photoréticulation d'un triacrylate: inhibition par les phénols et par l'oxygène, Thesis, Université Henri Poincaré - Nancy I, 1998.

[11] Haraguchi H., Ishikawa H., Sanchez Y., Ogura T., Kubo Y., Kubo I., Antioxidative constituents in Heterotheca inuloides, Bioorg. Med. Chem. 5 (1997) 865-871.

[12] Janin G., Colorimétrie : principe de la mesure de la couleur, in: Jodin P. (Ed.), Le bois, matériau d'ingénierie, ARBOLOR, Nancy, 1994, pp. 379-399.

[13] Kagan V.E., Serbinov E.A., Stoyanovsky D.A., Khwaja S., Packer L., Assay of ubiquinones and ubiquinols as antioxidants, Meth. Enzymol. 234 (1994) 343-354

[14] Klumpers J., Le déterminisme de la couleur du bois de chêne. Études sur les relations entre la couleur et les propriétés physiques, chimiques, anatomiques ainsi que les caractéristiques de croissance, Thesis, Engref, Nancy, 1994.

[15] Marcocci L., Suzuki Y.J., Tsuchyia M., Packer L., Antioxidant activity of nitecapone and its analog OR-1246: effect of structural modification on antioxidant action, Meth. Enzymol. 234 (1994) $526-541$.

[16] Martin F., Influence des substances extractibles sur le comportement photochimique du bois de chêne : propriétés antioxydantes de ces composés, Thesis, Université de Nancy I, 1996.

[17] Mazet J.F., Triboulot M.C., Merlin A., Janin G., Déglise X., Modification de la couleur du bois de chênes européens exposés à la lumière solaire, Ann. Sci. For. 50 (1993) 119-146.

[18] Mill T., Hendry D.G., Kinetics and mechanisms of free radical oxidation of akanes and olefins in the liquid phase, in: Bamford C.H., Tipper C.F.H. (Eds.), Chemical kinetics, Elsevier, Amsterdam, 1980, pp. 1-87.

[19] Mukai K., Watanabe Y., Uemoto Y., Ishizu K., Stopped-flow investigation of antioxidant activity of tocopherols, Bull. Chem. Soc. Jpn. 59 (1986) 3113-3116.
[20] Niki E., Free radical initiators as source of water- or lipid-soluble peroxyl radicals, Meth. Enzymol. 186 (1990) 100-108.

[21] Ohashi H., Kyogoku T., Ishikawa T., Kawase S.-I., Kawai S., Antioxidative activity of tree phenolic constituents I: Radicalcapturing reaction of flavon-3-ols with radical initiator, J. Wood Sci. 45 (1999) 53-63.

[22] Ohnishi M., Morishita H., Toda S., Yase Y., Kido R., Inhibition of in vitro linoleic acid peroxidation and haemolysis by caffeoyltryptophan, Phytochemistry 47 (1998) 1215-1218.

[23] Pizzi A., Tannin based adhesives, in: Pizzi A. (Ed.), Wood Adhesives Chemistry and Technology, Vol. 1, Marcel Dekker, New York, 1983, pp. 179-190.

[24] Pizzi A., Advanced Wood Adhesives Technology, Marcel Dekker, New York, 1994, pp. 155-176.

[25] Re R., Pellegrini N., Ptoteggente A., Pannala A., Yang M., RiceEvans C., Antioxidant activity: applying an improved ABTS radical cation decolorization assay, Free Rad. Biol. Med. 26 (1999) 12311237.

[26] Rousseau-Richard C., Auclair C., Richard C., Martin R., Free Radical scavenging and cytotoxic properties in the ellipticine series, Free Rad. Biol. Med. 8 (1990) 223-230.

[27] Rousseau-Richard C., Richard C., Martin R., Étude cinétique de l'influence complexe, pro ou antioxydante, de dérivés phénoliques sur l'oxydation induite d'un substrat polyinsaturé. I. Analyse du mécanisme réactionnel, J. Chim. Phys. 85 (1988) 167-173.

[28] Rousseau-Richard C., Richard C., Martin R., Étude cinétique de l'influence complexe, pro ou antioxydante, de dérivés phénoliques sur l'oxydation induite d'un substrat polyinsaturé. II. Oxydation du linolénate de méthyle pur ou en présence de phénol, de 3,5-di-tbutyl 4-hydroxy anisole, de 3,5-dit-bytyl hydroxy toluène ou de $\alpha-$ tocophérol, J. Chim. Phys. 85 (1988) 175-184.

[29] Schwarz K., Bertelsen G., Nissen L. R., Gardner P.T., Heinonen M.I., Hopia A., Huynh-Ba T., Lambelet P., McPhail D., Skibsted L.H., Tijburg L., Investigation of plant extracts for the protection of processed foods against lipid oxidation. Comparison of antioxidant assays based on radical scavenging, lipid oxidation and analysis of the principal antioxidant compounds, Eur. Food Res. Technol. 212 (2001) 319-328.

[30] Simic M.G., Pulse radiolysis in study of oxygen radicals, Meth. Enzymol. 186 (1990) 89-100.

[31] Singleton V.L., Rossi J.A. Jr., Colorimetry of total phenolics with phosphomolybdic-phosphotungstic acid reagents, Am. J. Enol. Viticult. 16 (1965) 144-58.

[32] Somers T.C., Evans M.E., Spectral evaluation of young red wines: anthocyanin equilibria, total phenolics, free and molecular sulfur dioxide, "chemical age", J. Sci. Food Agric. 28 (1977) 279-87.

[33] Wanasundara U.N., Shahidi F., Stabilization of canola oil with flavonoids, Food chem. 50 (1994) 393-396.

[34] Wang M., Jin Y., Ho C.-T., Evaluation of resveratrol derivatives as potential antioxidants and identification of a reaction product of resveratrol and DPPH radical, J. Agric. Food Chem. 47 (1999) 3974-3977.

[35] Wang P.-F., Zheng R.-L., Inhibitions of the autoxidation of linoleic acid by flavonoids in micelles, Chem. Phys. Lipids, 63 (1992) $37-40$.

[36] Wayner D.D.M., Burton G.W., Ingold K.U., Barclay L.R.C., Locke S.J., The relative contribution of vitamin E, urate, ascorbate and proteins to the total peroxyl radical trapping antioxidant activity of human blood plasma, Biochim. Biophys. Acta, 924 (1987) 408-419.

[37] Yoshida T., Mori K., HatanoT., Okumura T., Uehara I., Komagoe K., Fujita Y., Okuda T., Studies on inhibition mechanism of autoxidation by tannins and flavonoids. V. Radical-scavenging effects of tannins and related polyphenols on 1,1-diphenyl-2-picrylhydrazyl radical, Chem. Pharm. Bull. 37 (1989) 1919-1921. 